\title{
Prevalence of Chronic Periodontitis, Bruxism and Temporomandibular Joint Disorders in Patients with Fibromyalgia Syndrome
}

\author{
Fibromiyalji Sendromu Olan Hastalarda Kronik Periodontitis, \\ Bruksizm ve Temporamandibular Eklem Rahatsızlığı Prevalansı
}

\author{
Hatice Balcı Yüce ${ }^{1}$, Ahmet İnanır ${ }^{2}$, Özge Göktürk ${ }^{1}$, Hümeyra Aydemir Turkal ${ }^{1}$, Vildan Bostancı ${ }^{3}$ \\ ${ }^{1}$ Gaziosmanpaşa University Faculty of Dentistry, Department of Periodontology, Tokat, Turkey \\ ${ }^{2}$ Gaziosmanpaşa University Faculty of Medicine, Department of Physical Medicine and Rehabilitation, Tokat, Turkey \\ ${ }^{3}$ Cumhuriyet University Faculty of Dentistry, Department of Periodontology, Sivas, Turkey
}

Keywords

Bruxism, chronic periodontitis, fibromyalgia syndrome, temporomandibular joint disorders

Anahtar Kelimeler

Bruksizm, kronik periodontitis, fibromiyalji

sendromu, temporomandibular eklem

hastalıkları

Received/Geliş Tarihi : 01.11.2016

Accepted/Kabul Tarihi : 30.12.2016

doi:10.4274/meandros.98608

Address for Correspondence/Yazışma Adresi: Özge Göktürk MD,

Gaziosmanpaşa University Faculty of Dentistry, Department of Periodontology, Tokat, Turkey

Phone : +90 3562521580

E-mail : ozgedayioglu@hotmail.com

(C) Meandros Medical and Dental Journal, Published by Galenos Publishing House.

This is article distributed under the terms of the

Creative Commons Attribution NonCommercial 4.0

International Licence (CC BY-NC 4.0).

\begin{abstract}
Objective: Chronic periodontitis is a world-wide infectious and inflammatory disease and may have a relationship with other inflammatory diseases such as fibromyalgia syndrome (FMS). The aim of this study was to determine whether the prevalence of periodontitis is increased in individuals with FMS or not.

Materials and Methods: Sixty-four patients with FMS and 70 systemically healthy individuals were included in the present study. Fibromyalgia patients did not have any other systemically disease. All subjects had at least 20 functioning teeth and underwent detailed oral and radiographic examination, in addition, bruxism and temporomandibular joint (TMJ) examinations were performed. All clinical attachment levels, plaque and gingival indices were recorded.

Results: Fibromyalgia patients tend to have higher gingival index scores than healthy individuals. There was a significant difference in the presence of bruxism between the study groups $(p<0.05)$ but not in the presence of TMJ disorders. There was no significant difference regarding to periodontal disease between individuals under age 45 years. The prevalence of periodontitis was increased in healthy group aged above 45 years $(p<0.05)$ but not changed in equivalent FMS patients $(p>0.05)$. Conclusion: We found that the prevalence of periodontitis was not changed in FMS patients but was increased in healthy subjects above age 45 .
\end{abstract}

Öz

Amaç: Kronik periodontitis dünya çapında yaygın bir enfeksiyöz ve enflamatuvar hastalıktır ve fibromiyalji sendromu (FMS) gibi diğer enflamatuvar hastalıklar ile bir ilişkisi olabilir. Bu çalışmanın amacı, FMS ve kronik periodontitis arasında bir ilişki olup olmadığını tespit etmektir.

Gereç ve Yöntemler: Bu çalışmaya 64 FMS'li ve 70 sistemik sağlıklı hasta dahil edilmiş̧tir. Fibromiyalji hastalarının başka bir sistemik rahatsızlığı bulunmamaktadır. Tüm hastaların detaylı oral ve radyografik incelemeleri, bruksizm ve temporomandibular eklem (TME) muayenesi gerçekleştirilmiş ve ağızlarında en az 20 fonksiyonel diş bulunduğu doğrulanmıştır. Tüm klinik ataçman seviyeleri, plak ve gingival indeks skorları kaydedilmiştir. 
Bulgular: Fibromiyalji hastalarının gingival indeks skorları sağlıklı gönüllülere göre daha yüksek olarak bulunmuştur. Çalışma grupları arasında TME rahatsızı̆̆ı açııından fark bulunmazken, bruksizm açısından istatistiki anlamlı fark saptanmıştır $(p<0,05)$. Kırk beş yaş üstü hastalarda fibromiyalji ve periodontitis hastaları arasında negatif bir ilişki saptanırken, 45 yaşın altındaki bireylerde periodontal hastalık ile ilgili herhangi bir fark saptanmamıştır $(p<0,05)$.

Sonuç: Sonuçlar, FMS'nin periodontal problemleri arttırmadığını, ancak 45 yaşın üzerindeki hastalarda semptomlar için reçete edilen anti-enflamatuvar ve analjezik ilaçların, periodontal kayıpların şiddetini azaltabileceğini göstermektedir.

\section{Introduction}

Fibromyalgia syndrome (FMS) is a common chronic pain syndrome accompanied by some other symptoms such as stiffness, tenderness of specific anatomic sites (tender points), depression, anxiety, fatigue, sleep disturbances, irritable bowel syndrome and paresthesia $(1,2)$. FMS mostly affects females with a prevalence range 1-4\% (3-7). Along with other symptoms, diffuse pain and functional disability caused by FMS reduce the quality of life of patients $(1,8)$. Although mechanisms believed to be involved in the disease are unclear, there may be similarities with periodontitis pathogenesis, such as imbalance in oxidant/antioxidant status and up-regulation of pro-inflammatory cytokines. Furthermore, there is no study reporting any possible association between FMS and chronic periodontitis.

Neuroendocrine alterations are considered to play a major role in the development of $\operatorname{FSM}(9,10)$. In addition, a pro-inflammatory state in FMS has also been reported (8). Fibromyalgia usually is not considered as an inflammatory disease $(8,11,12)$. However, underlying mechanisms of the symptoms could be explained by over expression of certain cytokines responsible for immune and acute phase responses $(8,13)$. In addition to cytokines and inflammation, oxidative stress has been reported to be involved in the pathophysiology of FMS as well as periodontal diseases $(7,10,13)$. The role of oxidative stress in the etiopathogenesis of periodontal diseases is more evident than in FMS. To be specific, oxidant/ antioxidant imbalance either as a direct result of excessive reactive oxygen species production or antioxidant deficiency cause periodontal tissue destruction (14) and alveolar bone loss $(15,16)$. Unlike periodontitis, whether oxidative stress is an outcome or a causative factor in FMS is not clear (17-20).

Other than oxidative stress, there are a number of studies suggesting the involvement of innate immunity and increased cytokine profile in FMS $(21,22)$. The pro-inflammatory cytokines and mediators that have been found to be elevated are interleukin (IL)-6, IL-8, IL-10, tumor necrosis factor-alpha (TNF- $\alpha$ ), interferongamma, cortisol and C-reactive protein $(11,13,23,24)$. Along with these, an increase in neutrophil functions and up-regulation of monocyte derived IL-1 $\beta$, IL18 and monocyte chemoattractant protein-1 levels were reported by Bote et al. (25). These cytokines are related to acute inflammation and inflammatory diseases and also were found to be elevated in periodontitis patients. Particularly, TNF- $\alpha$ has a major role in soft and hard tissue destruction by modifying matrix degrading enzymes and receptor activator of nuclear factor kappa B ligand (26-29). TNF- $\alpha$ also upregulates other cytokines such as IL-1 $\beta$ and IL- 6 and accelerates the destructive process $(26,28,30-32)$.

There are also certain factors which were considered to be possible factors contributing to the development of FMS such as psychological factors (23), sleep disturbances and headache $(33,34)$ A relationship of bruxism with migraine headache (35) and sleep problems (36) was suggested. These factors are also either causative factors or results of bruxism suggesting a potential correlation. Furthermore, pain caused by FMS could also trigger bruxism. On the other hand, bruxism might cause pain in the orofacial muscles and temporomandibular joint (TMJ) which might severe FMS symptoms.

Based on these studies reporting possible common pathogenetic features between FMS and periodontitis, it is hypothesized that FMS patients might suffer more severe periodontitis than systemically healthy individuals. Therefore, the aim of the present study was to determine whether the prevalence of periodontitis is increased in individuals with FMS or not. The prevalence of bruxism and TMJ disorder is also evaluated in order to provide an opinion regarding any potential causes of muscle and/ or joint pain in the orofacial region and reveal any causative effect of FMS on bruxism. 


\section{Materials and Methods}

This clinical parallel study was conducted between March 2015 and June 2016 in the Department of Periodontology at the Faculty of Dentistry of Gaziosmanpaşa University. During this period, 64 patients diagnosed with FMS (FMS group) and 70 systemically healthy volunteers (HV group), totally 134 female patients were included in the study. The diagnosis of fibromyalgia was confirmed by consultation under Department of Physical Medicine and Rehabilitation, Gaziosmanpaşa University, Faculty of Medicine according to the American College of Rheumatology. FMS patients were currently not receiving any treatment aimed to control their symptoms. All the participants were non-smokers, had at least 20 teeth in their mouth and did not receive any periodontal treatment, use antibiotics or any drugs in the previous 6 months. Written informed consents were obtained. The study protocol was approved by Clinical Trials Ethics Committee of Gaziosmanpaşa University Faculty of Medicine, Tokat, Turkey (15-KAEK-158).

All FMS patients and HV underwent detailed oral and radiographic examinations. Clinical periodontal measurements of all teeth were recorded. Bruxism and TMJ examinations were performed clinically and radiographically.

\section{Periodontal Clinical Parameters}

The clinical measurements were recorded from cemento-enamel junction to the bottom of the pocket including gingival recessions if any. Chronic periodontitis and gingivitis were diagnosed based on the clinical and radiographic criteria defined by the 1999 International World Workshop for a Classification of Periodontal Diseases and Conditions (37). Full mouth clinical attachment level (CAL), probing pocket depth (PPD), plaque index (PI) (38), gingival index (GI) (39) measurements at six sites per tooth (mesial, middle and distal aspects of both buccal and lingual/ palatal surfaces) were performed. CAL and PPD levels were measured via a periodontal probe (Hu-Friedy Co., Chicago, IL, USA). CAL was calculated as the distance in millimeters from the cemento-enamel junction to the bottom of the periodontal pocket. PPD was measured in millimeters from the gingival margin to the base of the periodontal pocket.

\section{Bruxism and Temporomandibular Joint Examination}

Oral soft and hard tissue examination including jaw-muscle hypertrophy, linea alba in the cheeks, impressions of the teeth in the tongue or lips, tooth wear, and/or tooth or implant fracture, was performed and bruxism was diagnosed as per the following criteria:

1. A history of tooth grinding occurring $\geq 3$ nights per week,

2. Experience of morning jaw stiffness, and

3. Clinical presence of tooth wear $(40,41)$.

TMJ examination including pain history, palpation of the TMJs, compression and traction, auscultation of the TMJs for joint sounds, palpation of the masticatory muscles, limitations or disturbances of mandibular movements, dental status, and dynamic and static occlusion. Examination and diagnosis were performed according to the Research Diagnostic Criteria for Temporomandibular Disorders which classifies TMJ disorders into 3 groups as group 1 (muscle disorders), group 2 (disk displacement), and group 3 (arthralgia, osteoarthritis, and osteoarthrosis). Regarding TMJ disorder, presence of group 1 or further TMJ disorder was scored as ' 1 ' and absence was scored as ' 0 ' $(42,43)$. The same examiner, who was unaware of the treatment allocation, performed bruxism and TMJ examination in the participants.

\section{Intra-examiner Reproducibility}

One calibrated periodontics specialist, who was not aware of the study groups, performed all the measurements. The examiner underwent calibration training at the beginning of the study in order to provide standard measurements of CALs. The examiner examined 10 patients, not related to the present study, at two separate sessions, $48 \mathrm{~h}$ apart. Calibration was accepted if percentage agreement between measurements at baseline and after $48 \mathrm{~h}$ was more than $90 \%$.

\section{Statistical Analysis}

Data were expressed as mean and standard deviation, scores and percentage as appropriate. Analysis of normality was performed and parametric tests were used based on the distribution of the data. Independent samples t-test and chi-square test were used. All statistical analyses were performed via SPSS program (v.20.0) and a $p$ value of less than 0.05 was considered statistically significant. 


\section{Results}

Table 1 summarizes the results of this study. Mean age of the FMS and HV groups were 43.89 \pm 9.74 (27$63)$ years and $44.45 \pm 9.96$ (27-63) years, respectively. There were no significant differences in age and $\mathrm{PI}$ between the groups ( $p=0.74$ and $p=0.38$, respectively). The mean $\mathrm{PI}$ value was $1.70 \pm 0.63$ in FMS patients and $1.70 \pm 0.72$ in $\mathrm{HV}$, respectively. The mean GI value was $1.80 \pm 0.50$ in FMS group and $1.65 \pm 0.70$ in HV group. This difference was found to be statistically significant $(p=0.01)$. The mean CAL was $2.72 \pm 1.06$ and the prevalence of periodontitis was $15.62 \%$ in the FMS group while the values were $3.35 \pm 1.30$ and $41.42 \%$ in the HV group. There was a significant difference in CALs between the groups $(p=0.003)$. When quantitative data is converted to nominal data based on CAL values, as healthy and gingivitis=score 0 and periodontitis=score 1 , the chi-square test also showed significant difference $(p=0.001)$. When all participants were classified into three groups according to their age as young (age $\leq 30, n=8$ in FMS patients, $n=10$ in healthy group), early middle age (31-45, $n=24$ in FMS patients, $n=26$ in healthy group) and late middle age ( $\geq 46, n=32$ in FMS patients, $n=34$ in healthy group); the prevalence of periodontitis was 0 under age 30 in both groups, $14.28 \%$ in early middle aged FMS patients and $29.41 \%$ in early middle aged volunteers. There were no significant differences in periodontitis prevalence in both young and early middle aged participants between the two groups ( $p>0.05)$. The prevalence of periodontitis in late middle aged participants was $16.66 \%$ in FMS patients and $59.37 \%$ in volunteers (Figure 1). The difference was found

\begin{tabular}{|l|l|l|}
\hline \multicolumn{3}{|l|}{ Table 1. Summary of the results of the study } \\
\hline $\begin{array}{l}\text { Study groups/ } \\
\text { parameters }\end{array}$ & $\begin{array}{l}\text { FMS patients } \\
\mathbf{n}=64 \\
\text { Mean } \pm \text { SD }\end{array}$ & $\begin{array}{l}\text { Healthy } \\
\text { volunteers } \mathbf{n}=70 \\
\text { Mean } \pm \text { SD }\end{array}$ \\
\hline Age & $43.89 \pm 9.74$ & $44.45 \pm 9.96$ \\
\hline Plaque index & $1.70 \pm 0.63$ & $1.70 \pm 0.72$ \\
\hline Gingival index & $1.80 \pm 0.50$ & $1.65 \pm 0.70$ \\
\hline Probing pocket depth & $3.12 \pm 1.39 \mathrm{~mm}$ & $3.98 \pm 1.19 \mathrm{~mm}$ \\
\hline Bruxism prevalence & $0.46 \pm 0.59$ & $0.20 \pm 0.40$ \\
\hline TMJ disorder prevalence & $0.31 \pm 0.46$ & $0.18 \pm 0.39$ \\
\hline Clinical attachment level & $2.72 \pm 1.06 \mathrm{~mm}$ & $3.35 \pm 1.30 \mathrm{~mm}$ \\
\hline $\begin{array}{l}\text { SD: Standard deviation, FMS: Fibromyalgia syndrome, } \\
\text { TMJ: Temporomandibular joint }\end{array}$ \\
\hline
\end{tabular}

to be significant $(p=0.001)$. Furthermore, when CAL was classified into three categories as healthy, mild and medium attachment losses (CAL $\leq 3 \mathrm{~mm}=0, \mathrm{CAL}$ 3-5 $\mathrm{mm}=1$ and $\mathrm{CAL}>5 \mathrm{~mm}=2$ ); the rates in the FMS group were $84.37 \%, 3.13 \%$ and $12.50 \%$, respectively. The rates in the volunteers were $57.15 \%, 15.71 \%$ and $27.14 \%$, respectively.

The prevalence of TMJ disorder was 31\% and 19\% in FMS patients and $\mathrm{HV}$, respectively. The prevalence of bruxism was $50 \%$ and $20 \%$ in FMS patients and healthy individuals, respectively (Figure 2 ). The chisquare test results revealed a significant difference in bruxism $(p=0.001)$. Young and late middle aged FMS patients had higher prevalence of bruxism compared to young and early middle aged controls $(p=0.03$, $p=0.01$, respectively). However, no difference was found in the prevalence of TMJ disorders between the groups $(p=0.08)$.

\section{Discussion}

This is the first study to evaluate the relationship between FMS and chronic periodontitis. It was found that the prevalence of periodontitis increased with age in healthy individuals while remained the same in FMS patients. In order to evaluate cumulative effect of age on both periodontitis and FMS, age was assessed as three parts: young adults, early middle-aged adults and late middle-aged adults. The prevalence of

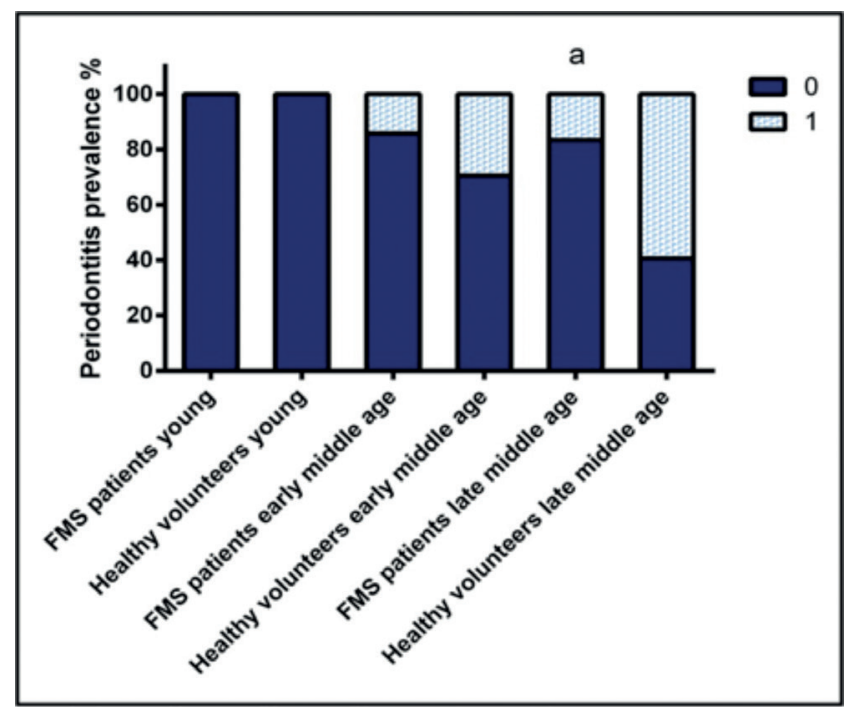

Figure 1. Periodontitis prevalence in fibromyalgia syndrome patients and healthy volunteers

0 : without periodontitis, 1 : with periodontitis, $a p<0.05$ vs. healthy volunteers late middle age, FMS: Fibromyalgia syndrome 
periodontitis in late middle-aged patients significantly increased in $\mathrm{HV}$ that could be interpreted as the effect of advancing age, however, the prevalence was same in equivalent FMS patients. It was shown that FMS patients had a higher prevalence of bruxism than healthy individuals but there were no TMJ disorders.

FMS is a disease of unknown etiology in which some factors are believed to be involved. These factors include psychosocial and environmental influences, neuroendocrine alterations (23), autonomic nervous systems problems, and genetic factors $(2,12)$. SantosGarcia et al. (3) confirmed that myocardial dysfunction that typically present in patients with FM, does not occur as a consequence of periodontitis. However, the fact that fibromyalgia patients have the low values of bleeding on probing while they have a high rate of dental plaque. This indicates very low susceptibility of patients to bleeding and thus periodontal disease. Unlike this report, it was found that PI was same between FMS and periodontitis patients while GI was higher in FMS patients. Though it is not a proved fact, this difference in $\mathrm{PI}$ and $\mathrm{GI}$ between the groups might result from unsteady oral hygiene behaviors of FMS patients which could be affected by general pain status of the patients. Similar to PI results, it was found that the prevalence of periodontitis was same in both groups under age 45 . The results also showed that the prevalence of periodontitis was increased in healthy

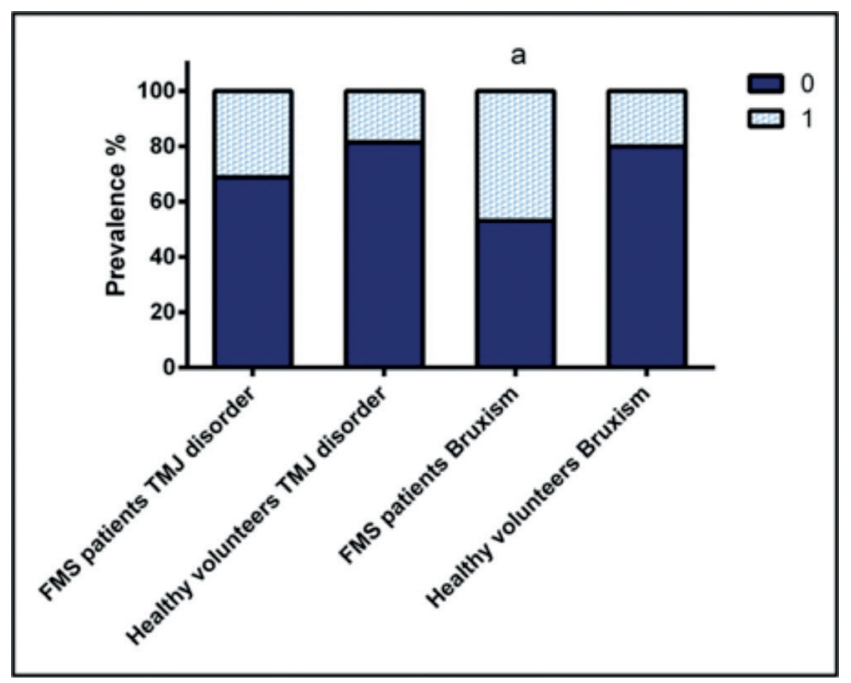

Figure 2. Bruxism and temporomandibular joint disorder prevalence in fibromyalgia syndrome patients and healthy volunteers

TMJ: Temporomandibular joint, FMS: Fibromyalgia syndrome, 0: without periodontitis, 1: with periodontitis, a $p<0.05$ vs. healthy volunteers bruxism prevalence group above 45 years of age. This result is compatible with the literature (44). However, interestingly, it was observed that FMS patients above 45 years of age had lower prevalence of periodontitis.

The etiology of FMS is not well-known, however, the number of studies evaluating the symptoms of FMS is rapidly increasing. Recently, it has been reported that FMS was associated with impairment of sexual functions in men (4). Furthermore, Gurbuzler et al (45). found that FMS caused vocal deteriorations such as decrease in vocal quality and intensity in women. In terms of genetics, Yigit et al. (12) demonstrated an association between IL-4 gene polymorphism and risk of FMS development. Fujarra et al. (46) evaluated TMJ disorder symptoms in FMS patients and found that FMS patients were suffering TMJ symptoms with muscle disorders, disc displacement and myofascial pain with limited mouth opening. Oral manifestations of FMS, such as TMJ dysfunction, xerostomia, hyposalivation and burning mouth syndrome have also been suggested $(34,47)$. Ghurye and McMillan (48) also suggested that pain in the TMJ might be associated with other chronic pain conditions such as FMS, irritable bowel syndrome and migraine. Pain caused by FMS might also trigger bruxism in patients and in order to evaluate this, the prevalence of bruxism and TMJ disorders were determined in the present study. As a result, it was found that FMS patients had a higher prevalence of bruxism but there were no pain or discomfort related to TMJ or any orofacial muscle function. In addition, none of the patients reported xerostomia, hypo-salivation or burning mouth in their dental and medical history. It might be reasonable to expect these problems in FMS patients as all these symptoms are somehow related to musculoskeletal malfunctions $(34,46,48)$. However, studies on oral manifestations of FMS or orofacial complaints of FMS patients are limited (49).

Apart from the factors responsible for FMS development, some predictors of FMS have been suggested. These predictors are pain in the neck and back, sleep disturbances, headache, and overweight $(33,34)$. Some of these could be related to another disorder with overlapping symptoms (34). Fibromyalgia patients generally use more antiinflammatory drugs for their chronic pain management (50). The use of modulating agents, including blocking production of pro-inflammatory cytokines and 
prostaglandins with anti-inflammatory drugs has been postulated to be of therapeutic value as an adjunctive therapy to the management of chronic periodontitis. Non-steroidal anti-inflammatory drugs may have a potential adjunctive role in periodontal therapy or at least decrease the severity of existing disease (51). FMS patients involved in the present study were not under drug therapy within the previous 6 months. Nevertheless, people with pain tend to use painkillers and effects of these drugs if any, would be clearer in time especially in long time periods such as 45 years. Un-changed prevalence values in patients above 45 years of age might be due to previous drug use which was not within the time period of the present study.

Any disease modifying immune response, influencing cytokine profile and/or disrupting oxidant/ antioxidant balance might be related to periodontal inflammation. The relationship between FMS and periodontal diseases to be better understood, parameters regarding to systemic inflammation, immune response and oxidative stress should be determined.

A limitation of the present study is that in this study, patients with FMS as well as systemically healthy group were chosen among the individuals who applied to the Faculty of Dentistry for their routine dental control or the treatment of various dental problems such as caries, and periodontal diseases. FMS group or systemic healthy group may have higher possibility of having periodontal diseases.

The present study evaluated only the clinical periodontal parameters, bruxism and TMJ problems and it was found that the prevalence of periodontitis was not changed in FMS patients, and plaque accumulation was same in both groups. Any biochemical parameters, such as gingival crevicular fluid and serum markers of inflammation and oxidative stress were not determined. An explanation for this limitation is that if there was a relationship, it should have manifested clinical changes in periodontal parameters.

\section{Conclusions}

In conclusion, it was found that the prevalence of periodontitis was lower in patients above 45 years of age. It was also found that FMS patients had an increased prevalence of bruxism and this could be due to the pain caused by FMS. TMJ disorders were not found to be related to FMS in our study. Studies with large samples and determining cytokine levels in serum and gingival crevicular fluid might help reveal other aspects of these two diseases that are not covered in this study.

\section{Ethics}

Ethics Committee Approval: The study protocol was approved by Clinical Trials Ethics Committee of Gaziosmanpaşa University Faculty of Medicine, (15KAEK-158), Informed Consent: Written informed consents were obtained.

Peer-review: Externally peer-reviewed.

\section{Authorship Contributions}

Surgical and Medical Practices: A.I., Ö.G., Concept: H.B.Y., Ö.G., Design: H.B.Y., H.A.T., Data Collection or Processing: H.B.Y., A.I., Analysis or Interpretation: H.B.Y., H.A.T., Literature Search: Ö.G., H.B.Y., Writing: H.B.Y., V.B.

Conflict of Interest: No conflict of interest was declared by the authors.

Financial Disclosure: The authors declared that this study received no financial support.

\section{References}

1. Wolfe F, Anderson J, Harkness D, Bennett RM, Caro XJ, Goldenberg DL, et al. Work and disability status of persons with fibromyalgia. J Rheumatol 1997; 24: 1171-8.

2. Bradley LA. Pathophysiology of fibromyalgia. Am J Med 2009; 122: 22-30.

3. Santos-Garcia R, Sanchez-Dominguez B, Cordero MD. Utility of Periodontal exploration in patients with Fibromyalgia. J Clin Exp Dent 2012; 4: 40-2.

4. Batmaz I, Sariyildiz MA, Dilek B, Inanır A, Demircan Z, Hatipoğlu $N$, et al. Sexuality of men with fibromyalgia: what are the factors that cause sexual dysfunction? Rheumatol Int 2013; 33: 126570.

5. Barth H, Klein R, Berg PA. L-tryptophan contaminant 'peak $E^{\prime}$ induces the release of IL-5 and IL-10 by peripheral blood mononuclear cells from patients with functional somatic syndromes. Clin Exp Immunol 2001; 126: 187-92.

6. Gur A, Karakoc M, Nas K, Remzi, Cevik, Denli A, et al. Cytokines and depression in cases with fibromyalgia. J Rheumatol 2002; 29: 358-61.

7. Su SY, Chen JJ, Lai CC, Chen CM, Tsai FJ. The association between fibromyalgia and polymorphism of monoamine oxidase $A$ and interleukin-4. Clin Rheumatol 2007; 26: 12-6.

8. Ortega E, Garcia JJ, Bote ME, Martín-Cordero L, Escalante $Y$, Saavedra JM, et al. Exercise in fibromyalgia and related inflammatory disorders: known effects and unknown chances. Exerc Immunol Rev 2009; 15: 42-65. 
9. Geenen R, Bijlsma JW. Deviations in the endocrine system and brain of patients with fibromyalgia: cause or consequence of pain and associated features? Ann N Y Acad Sci 2010; 1193: 98110.

10. Di Franco M, lannuccelli C, Valesini G. Neuroendocrine immunology of fibromyalgia. Ann N Y Acad Sci 2010; 1193: 84-90.

11. Blanco I, Janciauskiene S, Nita I. Low plasma levels of monocyte chemoattractant protein-1 (MCP-1), tumor necrosis factor-alpha (TNFalpha), and vascular endothelial growth factor (VEGF) in patients with alpha1-antitrypsin deficiency-related fibromyalgia. Clin Rheumatol 2010; 29: 189-97.

12. Yigit S, Inanir A, Tekcan A, Inanir S, Tural S, Ates O. Association between fibromyalgia syndrome and polymorphism of the IL-4 gene in a Turkish population. Gene 2013; 527: 62-4.

13. Sturgeon JA, Darnall BD, Zwickey HL. Proinflammatory cytokines and DHEA-S in women with fibromyalgia: impact of psychological distress and menopausal status. J Pain Res 2014; 7: 707-16.

14. Chapple IL, Matthews JB. The role of reactive oxygen and antioxidant species in periodontal tissue destruction. Periodontol 2000 2007; 43: 160-232.

15. Basu S, Helmersson J, Jarosinska D, Sallsten G, Mazzolai B, Barregard L. Regulatory factors of basal $F(2)$-isoprostane formation: population, age, gender and smoking habits in humans. Free Radic Res 2009; 43: 85-91.

16. D'Aiuto F, Nibali L, Parkar M, Patel K, Suvan J, Donos N. Oxidative stress, systemic inflammation, and severe periodontitis. J Dent Res 2010; 89: 1241-6.

17. Cordero MD, Moreno-Fernandez AM, deMiguel M, Coenzyme Q10 distribution in blood is altered in patients with fibromyalgia. Clin Biochem 2009; 42: 732-5.

18. Bagis S, Tamer L, Sahin G. Free radicals and antioxidants in primary fibromyalgia: an oxidative stress disorder? Rheumatol Int 2005; 25: 188-90.

19. Chung CP, Titova D, Oeser A, Randels M, Avalos I, Milne GL, et al. Oxidative stress in fibromyalgia and its relationship to symptoms. Clin Rheumatol 2009; 28: 435-8.

20. Ozgocmen S, Ozyurt H, Sogut S, Akyol O. Current concepts in the pathophysiology of fibromyalgia: the potential role of oxidative stress and nitric oxide. Rheumatol Int 2006; 26: 585-97.

21. Bazzichi L, Rossi A, Massimetti G, Giannaccini G, Giuliano T, De Feo $F$, et al. Cytokine patterns in fibromyalgia and their correlation with clinical manifestations. Clin Exp Rheumatol 2007; 25: 225-30.

22. Uceyler N, Hauser W, Sommer C. Systematic review with meta-analysis: cytokines in fibromyalgia syndrome. BMC Musculoskelet Disord 2011; 12: 245.

23. Tsilioni I, Russell IJ, Stewart JM, Gleason RM, Theoharides TC. Neuropeptides CRH, SP, HK-1, and Inflammatory Cytokines IL-6 and TNF Are Increased in Serum of Patients with Fibromyalgia Syndrome, Implicating Mast Cells. J Pharmacol Exp Ther 2016; 356: 664-72.

24. Mendieta D, la Cruz-Aguilera DL, Barrera-Villalpando $\mathrm{MI}$, Becerril-Villanueva E, Arreola R, Hernandez-Ferreira E, et al. IL-8 and IL-6 primarily mediate the inflammatory response in fibromyalgia patients. J Neuroimmunol 2016; 290: 22-5.
25. Bote ME, Garcia JJ, Hinchado MD, Ortega E. Inflammatory/ stress feedback dysregulation in women with fibromyalgia. Neuroimmunomodulation 2012; 19: 343-51.

26. Cekici A, Kantarci A, Hasturk H, Van Dyke TE. Inflammatory and immune pathways in the pathogenesis of periodontal disease. Periodontol 2000 2014; 64: 57-80.

27. Graves DT, Cochran D. The contribution of interleukin-1 and tumor necrosis factor to periodontal tissue destruction. J Periodontol 2003; 74: 391-401.

28. Graves DT, Fine D, Teng YT, Van Dyke TE, Hajishengallis G. The use of rodent models to investigate host-bacteria interactions related to periodontal diseases. J Clin Periodontol 2008; 35: 89105.

29. Garlet GP, Martins W, Jr., Fonseca BA, Ferreira BR, Silva JS. Matrix metalloproteinases, their physiological inhibitors and osteoclast factors are differentially regulated by the cytokine profile in human periodontal disease. J Clin Periodontol 2004; 31: 671-79.

30. Okada N, Kobayashi M, Mugikura K, Okamatsu Y, Hanazawa S, Kitano $S$, et al. Interleukin-6 production in human fibroblasts derived from periodontal tissues is differentially regulated by cytokines and a glucocorticoid. J Periodontal Res 1997; 32: 55969.

31. Kwan Tat S, Padrines M, Theoleyre S, Heymann D, Fortun Y. IL6, RANKL, TNF-alpha/IL-1: interrelations in bone resorption pathophysiology. Cytokine Growth Factor Rev 2004; 15: 49-60.

32. Dinarello CA. Proinflammatory cytokines. Chest 2000; 118: $503-$ 8.

33. Markkula RA, Kalso EA, Kaprio JA. Predictors of fibromyalgia: a population-based twin cohort study. BMC Musculoskelet Disord 2016; 17: 29.

34. Balasubramaniam R, Laudenbach JM, Stoopler ET. Fibromyalgia: an update for oral health care providers. Oral Surg Oral Med Oral Pathol Oral Radiol Endod 2007; 104: 589-602.

35. Kato M, Saruta J, Takeuchi M, Sugimoto M, Kamata Y, Shimizu T, et al. Grinding patterns in migraine patients with sleep bruxism: a case-controlled study. Cranio 2016; 34: 371-7.

36. Kostrzewa-Janicka J, Jurkowski P, Zycinska K, Przybyłowska D, Mierzwinska-Nastalska E. Sleep-Related Breathing Disorders and Bruxism. Adv Exp Med Biol 2015; 873: 9-14.

37. Armitage GC. Development of a classification system for periodontal diseases and conditions. Ann Periodontol 1999; 4: 1-6.

38. Silness J, Loe H. Periodontal Disease in Pregnancy. II. Correlation between Oral Hygiene and Periodontal Condtion. Acta Odontol Scand 1964; 22: 121-35.

39. Loe $H$. The Gingival Index, the Plaque Index and the Retention Index Systems. J Periodontol 1967; 38: (Suppl): 610-6.

40. Lobbezoo F, Ahlberg J, Glaros AG, Kato T, Koyano K, Lavigne GJ, et al. Bruxism defined and graded: an international consensus. J Oral Rehabil 2013; 40: 2-4.

41. Medicine AAoS. Diagnostic and Coding Manual. 2nd ed. Westchester, IL, USA, 2005.

42. Dworkin SF, Le Resche L. Research diagnostic criteria for temporomandibular disorders:review, criteria, examinations and specifications, critique. J Craniomandib Disord 1992; 6: 301-55. 
43. Buergers $\mathrm{R}$, Kleinjung $\mathrm{T}$, Behr $\mathrm{M}$, Vielsmeier $\mathrm{V}$. Is there a link between tinnitus and temporomandibular disorders? J Prosthet Dent 2014; 111: 222-7.

44. Ebersole JL, Graves CL, Gonzalez OA, Dawson D, Morford LA, Huja PE, et al. Aging, inflammation, immunity and periodontal disease. Periodontol 2000 2016; 72: 54-75.

45. Gurbuzler L, Inanir A, Yelken K, Koc S, Eyibilen A, Uysal IO. Voice disorder in patients with Fibromyalgia. Auris Nasus Larynx 2013; 40: 554-7.

46. Fujarra FJ, Kaziyama HH, Siqueira SR, Yeng LT, Camparis CM, Teixeira MJ, et al. Temporomandibular disorders in fibromyalgia patients: are there different pain onset? Arq Neuropsiquiatr 2016; 74: 195-200.

47. de Baat C, Gerritsen AE, de Baat-Ananta M, de Baat P. [The (putative) pathological impact of fibromyalgia on the orofacial system]. Ned Tijdschr Tandheelkd 2016; 123: 148-53.
48. Ghurye S, McMillan R. Pain-Related Temporomandibular Disorder - Current Perspectives and Evidence-Based Management. Dent Update 2015; 42: 533-45.

49. Balasubramaniam R, Laudenbach JM, Stoopler ET. Fibromyalgia: an update for oral health care providers. Oral Surg Oral Med Oral Pathol Oral Radiol Endod 2007; 104: 589-602.

50. Atzeni F, Masala IF, Salaffi F, DiFranco M, Casale R, Sarzi - Puttini P. Pain in systemic inflammatory rheumatic diseases. Best Pract Res Clin Rheumatol 2015; 29: 42-52.

51. Reddy MS, Geurs NC, Gunsolley JC. Periodontal host modulation with antiproteinase, anti- inflammatory, and bone-sparing agents. A systematic review. Ann Periodontol 2003; 8: 12-37. 